\title{
Acetylcholinesterase activity in copepods (Tigriopus brevicornis) from the Vilaine River estuary, France, as a biomarker of neurotoxic contaminants
}

\author{
J. Forget ${ }^{a_{*}}$, B. Beliaeff ${ }^{b}$ and G. Bocquenéc \\ 'Laboratoire d'Ecotoxicologie, UPRES-EA 3222, Faculté des Sciences et Techniques, Université du Havre, 25 \\ rue Philippe Lebon, BP540, 76058, Le Havre cedex, France \\ ${ }^{b}$ DEL AO, Ifremer, rue de l'lle d'Yeu, BP 1105, 44311, Nantes cedex 03, France \\ 'DEL PC, Ifremer, rue de I'lle d'Yeu, BP 1105, 44311, Nantes cedex 03, France \\ *: Corresponding author : Tel.: +33-2-32-74-43-79; fax: +33-2-32-74-43-14 joelle.forget@univ-lehavre.fr
}

\begin{abstract}
From April 1997 to June 1998, 14 measurements of acetylcholinesterase (AChE) enzymatic activity were performed with the copepod, Tigriopus brevicornis, collected at five stations in the Vilaine River estuary (South Brittany, France). Simultaneously, four chemical analyses of triazines and one analysis of total pesticides in water were undertaken. AChE activity levels in T. brevicornis were compared to the levels measured at a reference site not exposed to effluents from Vilaine River. Results reveal significant differences between AChE activity levels depending on location of stations in the plume of the river with an increasing gradient of activity from the upstream to the downstream stations, thus indicating that neurotoxic contaminants are mainly brought by the river. The average degree of AChE inhibition between the reference site and the most upstream site is $70-80 \%$ during spring in 1997 and 1998. In May 1997, live copepods from the different sites were brought back and transferred to clean seawater. After 14 days, recovery of AChE activity was almost total when compared to the control. Moreover, using a linear regression model and the atrazine concentration as marker of the presence of pesticides, low levels of AChE activity were significantly explained by atrazine concentration in water.
\end{abstract}

Keywords: Acetylcholinesterase activity; Tigriopus brevicornis; Pesticides; Pollution; Estuary; Monitoring 


\section{INTRODUCTION}

River effluents are one of the main source of chemical contamination of estuaries and deltas. In France, some are known to be contaminated by a wide range of pollutants (Abarnou et al., 2000 ; RNO, 1997) including metals (Chiffoleau et al., 1999), polycyclic aromatic hydrocarbons (PAHs) (Fernandes et al., 1997), pesticides, polychlorinated biphenyls (PCBs) and surfactants (Thompson et al., 1999). Furthermore, its was demonstrated that some of these contaminants can be found at potentially harmful concentrations in water (Matthiessen et al., 1993) and in sediments (Baumard et al., 1999 ; Den Besten et al., 2001). Pesticides were highlighted as potential estuarine contaminants (Kirby et al., 2000 ; Solé et al., 2000 ; Thomas et al, 1999). In most European countries, the use of organochlorine pesticides was restricted in recent years due to their environmental persistence and this has led to a great increase in the use of organophosphate (OP) and carbamate (C) alternatives. Although they are less persistent than organochlorine compounds, OP and $\mathrm{C}$ are generally more toxic and have been responsible for major ecological accidents such as the Sandoz accident in Switzerland in 1987 (Capel et al., 1988) and various fish kills (Salte et al., 1987 ; Horsberg et al., 1989 ; Zinkl et al., 1991). Organophosphate and carbamate insecticides are potent neurotoxic molecules and exert their toxicity by blocking the breakdown of acetylcholine by the enzyme acetylcholinesterase (AChE). Besides, complex mixtures of pesticides and metals were also revealed as strong inhibitors of cholinesterase systems (Bocquené et al., 1995 ; Forget et al., 1999).

Acetylcholine is the primary neurotransmitter in the sensory and neuromuscular systems in most species. The activity of this system is vital to normal behaviour and muscular function and represents a prime target on which some toxicants can exert a detrimental effect. Inhibition of the AChE enzyme results in a build up of acetylcholine causing a continuous and excessive stimulation of the nerve/muscle fibres which leads to tetany, paralysis and eventual death. Measurement of AChE inhibition in aquatic organisms has already been used as a biomarker of effects of neurotoxic contaminants (Habig and Di Giulio, 1988 ; Galgani et al., 1992 ; Payne et al., 1996 ; McHenery et al., 1997 ; Kirby et al., 2000 ; Solé et al., 2000).

To monitor the effects of neurotoxic contaminants in the marine environment, bivalve molluscs such as the common mussel (Mytilus edulis, Mytilus galloprovincialis) or the common oyster (Crassostrea gigas) have been used as favourite target species for the three past decades. However, molluscs proved to be less sensitive to inhibitors than crustacean or vertebrate species (Galgani and Bocquené, 1990 ; Bocquené et al., 1997 ; Forget et al., 1999). A previous study showed that acetylcholinesterase from $T$. brevicornis was as sensitive as AChE from insects to inhibitory effects of most OP and C (Forget and Bocquené, 1999). In order to check that apparent depression in cholinesterase activity was not only due to phylogenetic differences in T. brevicornis, in the present study AChE activity was monitored in animals which were brought back from the different sites and put into clean sea-water for 7 and 14 days.

The Vilaine River was selected for this study for two main reasons : i) Brittany is primarily devoted to agriculture and the Vilaine catchment area drains one third of Britton waters, being consequently subject to potential contamination by pesticides ; ii) Shellfish ressources, mainly through mussel farms, are highly developed in the estuary of the Vilaine River.

The wide distribution of T. brevicornis (it is present in all intertidal pools around the mouth of the «Vilaine») and existence of a single form of a very sensitive acetylcholinesterase make this copepod a potential bioindicator of inhibitory effects, and more generally for biological effects monitoring in coastal waters.

This study was designed to ascertain whether evidence of neurotoxicity was apparent in the mouth of the Vilaine River, using the measurement of AChE activity in the copepod $T$. 
brevicornis. Chemical analysis of intertidal pool water from the five sampling sites was also undertaken for a range of pesticides in an attempt to link AChE levels observed to the presence of potent neurotoxic contaminants.

\section{MATERIALS AND METHODS}

\section{1 - Location of sampling sites}

Sites are located in the estuary of the Vilaine River on the western coast of France (France, South Britanny, figure 1). Location of the sampling stations (1 : Le Halguen, 2 : PenLan, 3 : Kervoyal, 4 : Port au Loup) follows a gradient of dilution of the Vilaine River into the marine waters. Le Croisic (station 5) was chosen as the reference site. This station is located on the offshore part of a peninsula far from any agricultural inputs or riverine waters (figure 1). 
Figure 1 : Location of sampling stations of T. brevicornis in the estuary of the Vilaine River (South Brittany, France).

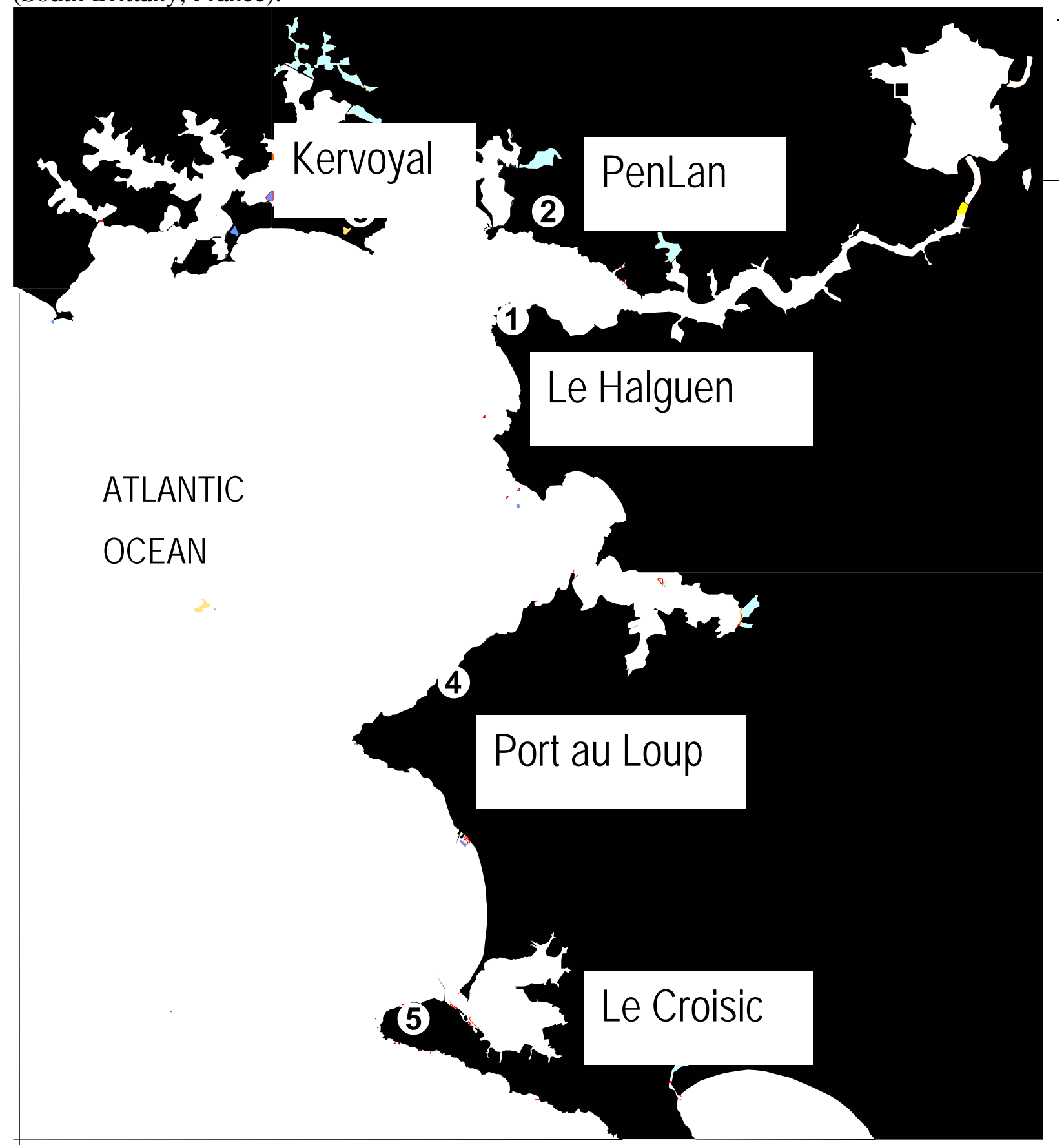

\section{2 - Sampling}

Sampling of Tigriopus brevicornis

From April 1997 to June 1998, T. brevicornis were collected monthly from intertidal pools along the rocky shore line of the Vilaine estuary and from the reference site Le Croisic. Living copepods were immediately frozen in carbonic ice at $-80^{\circ} \mathrm{C}$ for measurement of AChE activity. In the hottest Summer conditions some pools totally desiccated whereas storms 
prevented us sampling on some Winter occasions resulting in the absence of some sampling times.

Samples of $T$. brevicornis were stored in liquid nitrogen $\left(-180^{\circ} \mathrm{C}\right)$ for $24 \mathrm{~h}$ before laboratory analysis.

Chemical determination of pesticides

Sampling dates were determined according to agricultural treatments in the «Vilaine» area.

Samples of water from intertidal pools ( $20 \mathrm{~L}$ ) were collected at $50 \mathrm{~cm}$ below the surface using a peristaltic Teflon pump. Samples were transported in clean borosilicate bottles and extraction of pesticides was immediately undertaken. Over a year period, this process was replicated four times on the five stations (May 23, 97; March 23, 98; May 26, 98 and June 3, 98). Chemical analysis was performed within 48 hours after sampling.

\section{3 - Cholinesterase assay procedure}

The whole body of T. brevicornis was used to determine AChE activity. Homogenates were obtained from a pool of 200 individuals after suspension with metal-blade homogenizer in $0,02 \mathrm{M} \mathrm{pH} 7$ phosphate buffer $+0,1 \%$ Triton X100 ( 1/4 v/w). The homogenates were then centrifuged at $10,000 \mathrm{~g}$ for $30 \mathrm{~min}$ at $4^{\circ} \mathrm{C}$. Measurements of AChE activity were performed using the colorometric method of Ellman (Ellman et al., 1961) with acetylthiocholine iodide (AcSCh) as substrate and dithiobisnitrobenzoate (DTNB) as reagent at a controlled temperature of $20^{\circ} \mathrm{C}$. Braford's method (Bradford, 1976) was used for quantitative determination of proteins with bovine serum albumin (BSA) as standard. These methods were adapted for measurement using a microplate reader (Bocquené and Galgani., 1998). All assays were performed in quadruplicate. Specific activity is expressed as nmoles of AcSCh hydrolyzed $\mathrm{min}^{-1} \cdot \mathrm{mg}^{-1}$ protein.

\section{4 - Recovery in clean seawater:}

To observe an eventual recovery of AChE activity, living T. brevicornis were brought back from the 5 sites and transferred to reference clean seawater $(\mathrm{pH} 8,30 \% \mathrm{NaCl}, 0.22 \mu \mathrm{m}$ filtered offshore seawater). Assays were conducted on 200 adults/site. All tests were performed at $20^{\circ} \mathrm{C} \pm 1^{\circ} \mathrm{C}$ using a $12: 12 \mathrm{~h}$ light: dark photoperiod in a culture chamber. Determination of cholinesterase activity was performed on 100 individuals after 7 and 14 days in clean seawater.

\section{5 -Chemical determination of pesticides}

Extraction of pesticides from samples of water was performed by solid-phase extraction (SPE) in columns filled with XAD-2 resin (Rhone Poulenc). All pesticide analysis were performed using a high resolution gas chromatography (GC) with NP detector (Varian GC 3400 equipped with a Nitrogen-Phosphorus detector and a Septum Programmable injector). One $\mu \mathrm{L}$ of calibration standard or sample extract was injected.

\section{6 - Statistical analysis of data}

A linear multiple regression model (Draper and Smith, 1966) was used to analyse variations of AChE activity from T. brevicornis as a possible function of temperature, salinity, $\mathrm{pH}$, concentration of atrazine (as a global marker of pesticide contamination) measured in intertidal pool water. A site effect was also added to the model to take into account betweensite differences in mean AChE activity levels. Finally, time (date) was added in the model as 
quantitative variable to account for a possible common trend of AChE activity among sites. Multiple comparison of AChE mean levels were performed using the Turkey method.

\section{RESULTS}

\section{1 - In situ AChE activity in T. brevicornis}

Mean AChE activity levels in pooled individuals of T. brevicornis collected in five stations of the Vilaine River estuary at different times of years 1997 and 1998 are reported in figures 2 and 3. The levels of AChE activity showed significant differences in relation to space and time. Copepods from Station 1 most often exhibited the lowest specific activities while the highest activities were measured in the animals from the reference site (Le Croisic). Between site differences in AChE activity levels were sometimes considerable. For example in April 1997, the mean activity in T. brevicornis from station 1 was $23 \pm 2.8$ nmoles.min ${ }^{-1} \cdot \mathrm{mg}^{-1}$ protein, was significantly lower $(\mathrm{p}<0.05)$ than the mean level of $137 \pm 10$ nmoles.min $^{-1} \cdot \mathrm{mg}^{-1}$ protein in copepods estimated from the reference site (station 5). The difference in levels of AChE activity reached 70-80 \% during the Spring season in 1997 and 1998. The residual activity can be given as the ratio of the AChE activity in copepods from an impacted station to that in animals from a reference station. When comparing stations 1 and 5 in April 1997, a $83.2 \%$ depression in activity at station 1 was recorded. It can be noted that the difference between sites were the lowest from August to January while the highest values of ratio were found from March to July (mainly the spring period). In the follow-up of AChE activity, two episodes of lower activities could clearly be distinguished: in June and July 1997 activities measured in copepods from stations 1 and 3 showed a clear decrease while the activity in the other stations still increased. From April to June, the same observation could be made.

\section{2 - Recovery of AChE activity in clean marine water}

A huge reactivation of the AChE enzyme was observed when copepods from stations 1, 2, 3 and 4 were placed in clean marine water for fourteen days or even for seven days only (figure 4). AChE activity increased in animals from all sites but particularly in those sampled in (station 1) whose levels jumped from 37 to 300 nmoles. $\mathrm{min}^{-1} \cdot \mathrm{mg}^{-1}$ protein after 14 days. Conversely, AChE activity in animals from station 5 (reference site), considered as the reference uncontaminated site in the present study, did not significantly $(p<0.05)$ increased, even after 14 days in clean marine water. 
Figure 2 : Variations of AChE activity levels in Tigriopus brevicornis sampled in the Vilaine estuary from April 1997 to June 1998. AChE activity is expressed in nmoles AcSCh hydrolysed. $\mathrm{min}^{-1} \cdot \mathrm{mg}^{-1}$ protein.




Figure 3 : Comparison between AChE activity levels in T. brevicornis (in nmoles of AcSCh hydrolysed.min ${ }^{-}$ ${ }^{1} . \mathrm{mg}^{-1}$ protein) and atrazine concentrations (in ng. $\mathrm{L}^{-1}$ ) in water collected in intertidal pools in five station of the Vilaine River estuary at four periods in spring 1997 and 1998.
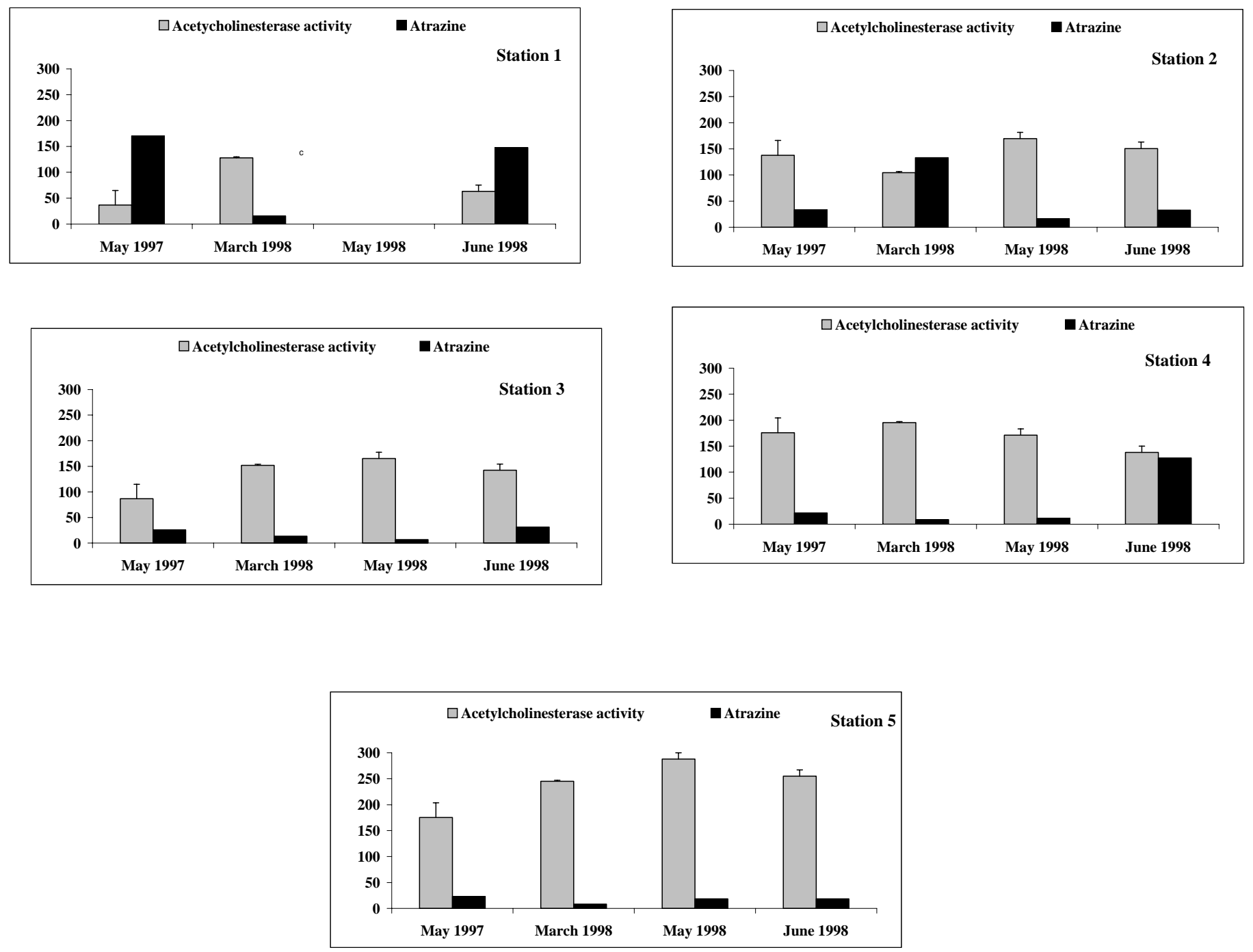
Figure 4 : Time-course recovery in clean marine water of AChE activity levels in $T$. brevicornis sampled from several sites of the Vilaine estuary in May 1997.






\section{3 - Chemical contamination of rock pool water in the Vilaine estuary}

A total of seventeen contaminants were identified in water samples collected in intertidal pools at stations 1 and 2, the most upstream stations in the Vilaine estuary, whereas only ten of those compounds could be detected in samples from the three other sites. Among researched compounds in dissolving phase, pesticides identified in the different samples were mainly herbicides belonging to the group of triazines (atrazine, metribuzine, simazine, terbutryne, prométon, propazine, secbuméton, terbuméton), amids (alachlore, propanil, tebutame), oxadiazoles (oxadiazon), and toluidines (trifuraline). Fungicides, belonging to piperidines (fenpropidine), morpholines (fenpropimorphe), phenylamids (metalaxil), and derived from oxazolidine (vinchlozoline) were also identified in the different water samples. The presence of the organophosphate insecticide methylparathion was suspected (but not confirmed by GC-MS spectrometry) at the upstream sites of the Vilaine estuary, on March 23, 1998. Triazines were present at concentration ranges of 7-148 and 4-33 ng. $\mathrm{L}^{-1}$ for atrazine and simazine, respectively (Table 1).

Table 1 : Concentrations of triazines (in ng. $\mathrm{L}^{-1}$ ) in water samples from intertidal pools in five stations of the Vilaine estuary. See figure 1 for precise location of sampling sites.

\begin{tabular}{lcc|cc|cc|cc|cc}
\hline & \multicolumn{2}{c}{ Kervoyal (3) } & \multicolumn{2}{c}{ PenLan (2) } & \multicolumn{2}{c}{ Le Halguen (1) } & \multicolumn{2}{c}{ Port au Loup (4) } & \multicolumn{2}{c}{ Le Croisic (5) } \\
\hline & Atrazine & Simazin & Atrazine & Simazin & Atrazine & Simazin & Atrazine & Simazin & Atrazine & Simazin \\
& & $\mathrm{e}$ & & $\mathrm{e}$ & & $\mathrm{e}$ & & $\mathrm{e}$ & & $\mathrm{e}$ \\
$23 / 05 / 97$ & 26 & 26 & 33 & 30 & 170 & 33 & 26 & 20 & 23 & 20 \\
$23 / 03 / 98$ & 13 & 6 & 133 & 12 & 16 & 9 & 9 & 7 & 8 & 6 \\
$26 / 05 / 98$ & 7 & 4 & 16 & 10 & - & - & 11 & 9 & 13 & 8 \\
$3 / 06 / 98$ & 31 & 5 & 33 & 3 & 148 & 14 & 128 & 19 & 19 & 6 \\
\hline
\end{tabular}

\section{DISCUSSION}

The surveys we performed here have shown that it is possible to significantly discriminate levels of AChE activity measured in T. brevicornis between sites in the Vilaine estuary. On the assumption that copepods sampled from the reference site exhibited "normal » levels of activity, then the supposedly more impacted sites were showing low levels of AChE. In April 1997, samples from Le Halguen (station 1) showed AChE inhibition levels of $83 \%$ in comparison to reference site. In ranking the sites with respect to levels of potential neurotoxicity measured in copepod T. brevicornis, we found, in decreasing order, Le Halguen, Kervoyal, PenLan, Port au Loup and Le Croisic (Station 1,3,2,4 and 5). This gradient corresponds to the spatial distribution of AChE inhibition in copepod from the Vilaine estuary and shows the existence of a clear downstream trend caused by upstream sources of AChE inhibitors. Such gradients of neurotoxicity observed through inhibition of acetylcholinesterase were also found in flounder in several UK estuaries (Kirby et al., 2000) as well as in the dab in the North Sea (Galgani et al., 1992) and in the common mussel in the delta of the Ebro river (Solé et al., 2000).

The highest levels of AChE activity in T brevicornis are measured in Summer decreasing to minimum in Winter. AChE activities are known to vary according to seasons (Gibson et al., 1969 ; Hogan , 1970 ; Bocquené et al., 1997) with the highest values being found during Summer. This is particularly true for cholinesterase activity in fish (Galgani and Bocquené, 1998). Most enzymatic activities in poikilothermic species vary with the temperature of their 
environment. Actually, level of cholinesterase activity does not directly depend on ambient temperature but on the physiological activity which is tightly correlated to water temperature. Variations of biotic parameters such as sex, size, age, gonadal maturity or starvation are know to influence biological markers and make the environmental significance of markers difficult for interpretation. However, Forget (1998) reported no significant influence of the gender on AChE activity but a higher specific activity in early nauplius stages of $T$. brevicornis. The same author found no significant modification of AChE activity during a 15 day period of starvation. Taking into account that measurements were carried out on selected adults of copepods, eventual influences of this type could be discarded. For what concerns the effects of salinity, a significant decrease in AChE activity was observed with salinity higher than 55\%o (Forget, 1998). This concentration has been reached only once, in September 1997, and might be the main reason for low AChE activities at this period.

The use of recovery techniques could be specifically used in environmental monitoring especially when a suitable control site is not available. Recovery of ChE activity after inhibition can occur spontaneously in uncontaminated marine water. It allows recovery of inhibited ChE activity in fresh tissues to normal levels and therefore could allow the determination of the level of inhibition attributable to pollutants having a neurotoxic effect. Reactivation techniques were used in this study to confirm that the low in situ AChE activity levels were indeed attributable to anti-ChE pollution and not to any phylogenetic variability (natural difference between copepod populations).

The regression model enabled us to confirm a significant site effect. After testing several submodels, it appears that atrazine was the most influencing factor on AChE levels variability in the five sampling water sites. The final model consists in a simple linear regression equation: $\log _{10}(\mathrm{AChE})=2.27-0.003 *$ [Atrazine] $\left(\mathrm{R}^{2}=0.64\right)$, and concludes that there is a significant $(\mathrm{p}<0.05)$ linear relation between AChE activity levels in Tigriopus brevicornis and atrazine concentration (contamination level). Spatio-temporal effects were captured by atrazine concentration variations. There were no significant effects for $\mathrm{pH}$, temperature and salinity (data not shown).

Actually, as herbicides, triazines are not direct cholinesterase inhibitors (Bocquené et al., 1995) although Davies et al., (1994) have made evidence of depression of AChE activiy after treatment of rainbow trout (Salmo truta) with $2 \mu \mathrm{g} . \mathrm{L}^{-1}$ of cyanazine. In the present study, triazines have only been monitored as a general marker of agricultural uses, mainly because of their conservative behaviour and because these molecules were easily detectable. Betweenstation high differences in triazine concentrations were observed. The most contaminated station was Le Halguen whereas Kervoyal and Le Croisic were the least ones. Besides, atrazine concentrations were much higher in downstream stations (3 and 4) on June 1998 after a heavy rain period. The peak of atrazine concentration observed in PenLan in March 1998 can be explained by a preferential circulation of low salinity waters to the northern part of the estuary; the salinity measured in the sampled pools on that day in PenLan was as low as $18 \%$. Due to their conservative biochemichal behavior, both atrazine and simazine could be quantified in our samples. In fact, they are associated with many other herbicides, fungicides and insecticides. For instance, carbofuran, a strong AChE inhibitor is often detected in the river Oust, the main tributary of the Vilaine River, at concentrations up to $0.25 \mu \mathrm{g} . \mathrm{L}^{-1}$ (Gillet, 1994) as a result of a 18,000 ton yearly dispersion on the watershed. This is all the more significant that carbamates (Cs) as well as organophosphorous (Ops) are rapidly degraded in the environment, in contrast to triazines (Lartigues and Garrigues, 1993). Thus, atrazine high concentrations in intertidal pools are most certainly accompanied by other less persistent agrochemicals, such as OPs and Cs. OPs and Cs insecticides are considered to be the most potent cholinesterase inhibitors among the panel of possible environmental contaminants (Bocquené et al., 1996). Belden and Lydy (2000) indicated also that the presence of atrazine 
can increase the toxicity of OPs of at least two times the expected valued to the midge Chironomus tentans, the increase in the toxicity in toxicity is thought to be due to an increase in biotransformation rates of OPs, resulting in more O-analog within the organisms. Although OPs and Cs are relatively non-persistent in the aquatic environment and consequently difficult to identify, their potency is such that their use remains a concern, and most AChE monitoring programmes were designed in view of detection of the effects of these contaminants. Buttressed by this study, AChE results seem to indicate that these insecticides could be present at chronically toxic levels in certain French, English or Spanish estuaries (Kirby et al., 2000 ; Solé et al., 2000).

Chemical analyses undertaken in the water revealed seventeen different compounds in Le Halguen, Kervoyal and Penlan (stations 1, 2 and 3). Not only may the sum of all these compounds reach levels of significance in terms of anticholinesterase effect, but, moreover, combinations of OPs and Cs were shown to be highly synergistic in their ability to inhibit AChE activity (Bocquené et al., 1995 ; Forget et al., 1999). Secondly these insecticides were determined only in water, but many of these molecules are relatively non-polar contaminants and may be associated with the sediment, or alternatively, bioaccumulate in organisms, as

Solé et al. (2000) demonstrated in the mussel. Therefore, exposure via sediment or dietary path could be a contributory factor in the total exposure of copepods to neurotoxic compounds. However, a number of other contaminants were shown to have anti-AChE properties, including heavy metals (Zinkl et al., 1991 ; Forget et al., 1999), hydrocarbons and detergents (Payne et al., 1996). The reduction in AChE activity observed in this study, if caused by pollution, should therefore be attributed to integrated effects of several classes of contaminants.

Due to agricultural practices, spring is the main period of the year where these contaminants are likely to be found at high concentrations in the Vilaine River and correspond to the lower AChE activity in the organisms tested. Same patterns were observed in the delta of Ebro with Mytilus galloprovincialis (Escartin and Porte, 1997) and in the La Rochelle bay. using $M$. edulis (Radenac et al., 1998). Shigehisa and Shiraishi (1998) observed the same trend in the river Kokaï in Japan, with a freshwater shrimp, Paratya compressa improvisa.

These results seem to prove that contamination of intertidal pools is also representative of inputs in environment dynamic seawater. In other terms, the ecosystem pool is not completely isolated from his direct environment, as the biological effects observed in this pool were also measured in the nearby seawater.

\section{CONCLUSION}

It was shown that in the Vilaine River estuary, Le Halguen was the most contaminated station with correspondingly low AChE activity in T. brevicornis while the Le Croisic reference station presented the lowest levels of contamination and significantly higher AChE activities. Evidence from the present study confirms that the measurement of ChE is a valuable tool that should be incorporated to a battery of biomarkers to maximize the confidence with which ecotoxicologists assess impacts of sub-lethal pollution in the marine and estuarine environment. As used in other organisms, like molluscs and echinoderms, and fish (Bocquené et al., 1990 ; Den Besten et al., 2001 ; Kirby et al., 2000 ; Solé et al., 2000), AChE appears as a relevant mean of investigating biological effects of many neurotoxic contaminants on aquatic habitats and trophic levels.

\section{Acknowledgements}


The authors wish to thank Jacek TRONCZYNSKI (IFREMER), Karine MOISAN (IFREMER) and Hélène BUDZINSKI (University of Bordeaux I) for their assistance in chemical analysis and Lon Peters for his comments on the manuscript.

\section{REFERENCES}

Abarnou, A., Burgeot, T., Chevreuil, M., Leboulenger, F., Loizeau, V., Madoulet-Jaouen, A., Minier, C., 2000. Les contaminants organiques : quels risques pour le monde vivant ?. Programme scientifique Seine Aval, 13, Ifremer, Paris.

Baumard, P., Budzinski, H., Garrigues, P., Narbonne, J.F., Burgeot, T., Michel, X., Bellocq, J., 1999. Polycyclic aromatic hydrocarbon (PAH) burden of mussels (Mytilus sp.) in different marine environments in relation with sediment PAH contamination, and bioavailability Mar. Environ. Res. 47, 415-439.

Bocquené, G.,. Bellanger, C., Cadiou, Y., 1995. Joint action of combinations of pollutants on the acetylcholinesterase activity of several marine species. Ecotoxicology 4, 266-279.

Bocquené, G., Galgani, F., Walker, C.H., 1997. Les cholinestérases, biomarqueurs de neurotoxicité. In Biomarqueurs en Ecotoxicologie: Aspects fondamentaux.. Masson, Paris,pp 209-240.

Bocquené, G., Galgani, F., 1998. Biological effect contaminants : cholinesterase inhibition by organophosphate and carbamate compounds. ICES. Tech. Mar. Environ. Sci, 22, 1-12.

Bradford, M., 1976. A rapid and sensitive assay of protein utilizing the principle of dye binding. Analyt. Biochem. 772, 248-264.

Capel, P., Giger, W., Reichert, P., Wanner, O., 1988. Accidental input of pesticides into the Rhine river. Environ. Sci. Technol. 22, 992-997.

Chiffoleau, J. F., Gonzalez, J. L., Miramand, P., Thouvenin, B., 1999. Le cadmium : comportement d'un contaminant métallique en estuaire. Programme scientifique Seine Aval, 10, Ifremer, Paris.

Davies, P.E., Cook, L.S.J., 1994. Sublethal responses to pesticides of several species of australian freshwater fish and crustaceans and rainbow trout. Environ.Toxicol.Chem. 13(8), 1341-1354.

Den Besten, P. J., Valk, S., Van Weerlee, E., Nolting, R.F., Postma, J.F., Everaats, J.M., 2001. Bioaccumulation and biomarkers in the sea star Asteria rubens (Echinodermata: Asteroida) : a North Sea field study. Mar. Environ. Res. 51, 365-387.

Draper, N.R., Smith, H., 1966. Applied regression analysis. John Wiley and Sons, New-York.

Ellman, G., Courtney, K., Andres, V., Featherstone, R.M., 1961. A new and rapid colorimetric determination of acetylcholinesterase activity. Biochem. Pharmacol. 7, 88-95.

Escartin, E., Porte, C., 1997. The use of cholinesterase and carboxylesterase activities from Mytilus galloprovincialis in pollution monitoring. Environ. Toxicol. Chem. 16, 2090-2095.

Fernandes, M. B., Sicre, M. A., Boireau, A., Tronczynski, J., 1997. Aquatic hydrocarbon distributions in the Seine estuary : biogenic polyaromatics and n-alkanes. Estuaries 20, 281290.

Forget, J., 1998. Neurotoxic impact of contaminants on the acetylcholinesterase activity of the marine copepod Tigriopus brevicornis (Müller). PhD Thesis. University of Paris VI. 180 pp.

Forget, J., Bocquené, G., 1999. Partial purification and enzymatic characterization of acetylcholinesterase from the intertidal marine copepod Tigriopus brevicornis. Comp. Biochem. Physiol. B123, 345-350.

Forget, J., Pavillon, J. F., Beliaeff, B., Bocquené, G., 1999. Joint action of pollutant combinations (pesticides and metals) on survival ( $\mathrm{LC}_{50}$ values) and acetylcholinesterase 
activity of Tigriopus brevicornis (copepoda, harpacticoïda). Environ. Toxicol. Chem. 18, 912-918.

Galgani, F., Bocquené, G., 1990. In vitro inhibition of acetylcholinesterase from four marine species by organophosphates and carbamates. Bull. Environ. Contam. Toxicol. 45, 243-249.

Galgani, F., Bocquené, G., Cadiou, Y., 1992. Evidence of variation in cholinesterase activity in fish along a pollution gradient in the North Sea. Mar. Ecol. Progr.Ser. 91, 77-82.

Galgani, F., Bocquené, G., 1998. Biomarqueurs moléculaires d'exposition des organismes marins aux pesticides organophosphorés et carbamates. In : Lagadic, L., Caquet, T., Amiard, J.C., Ramade, F. (Eds), Utilisation des biomarqueurs pour la surveillance de la qualité de l'environnement. Tec \& Doc Lavoisier, Paris, pp 111-134.

Gibson, J. R., Ludke, J. L., Ferguson, D. E., 1969. Source of error in the use of fish brain acetylcholinesterase activity as a monitor of pollution. Bull. Environ. Contam. Toxicol. 4, 1723.

Gillet, H., 1994. Etude de la contamination des eaux superficielles de Bretagne par les pesticides. Résultats du suivi de 1993. Prefecture de la Région Bretagne CORPEP, Rennes.

Habig, C., Di Giulio, R. T., 1988. The anticholinesterase effects of the cotton defoliant S, S, S, - Tri-n-Butyl Phosphorotrithioate (DEF) on channel catfish. Mar. Environ. Res. 24, 193197.

Hogan, J. W., 1970. Water temperature as a source of variation in the specific activity of brain cholinesterase of bluegills. Bull. Environ. Contam. Toxicol. 5, 347-354.

Horsberg, T.E., Hoey, T., Nafstad, I., 1989. Organophosphate poisoning of Atlantic salmon in connection with treatment against salmon lice. Acta. Vet. Scand. 30, 385-390.

Kirby, M.F., Morris, S., Hurst, M., Kirby, S.J., Neall, P., Tylor, T., Fagg, A., 2000. The use of cholinesterase activity in flounder (Platichthys flesus) muscle tissue as a biomarker of neurotoxic contamination in UK estuaries. Mar. Poll. Bull. 40, 780-791.

Lartigues, S., Garrigues, P., 1993. Determination of organophosphorus and organonitrogen pesticides in water and sediments by GC-NPD and GC-MS. Analusis 21, 157-165.

Belden, J.B., Lydy, M.J., 2000. Impact of atrazine on organophosphate toxicity. Environ. Toxicol. CHem. 19 : 2266-2274.

Matthiessen, P., Thain, J., Law, R.J., Fileman, T.W., 1993. Attempts to assess the environmental hazard posed by complex mixtures of organic chemicals in UK estuaries. Mar. Pollut. Bull. 26, 90-95.

Mc Henery, J.G., Linley-Adams, G.E., Moore, D.C., Rodger, G.K., Davies, I.M., 1997. Experimental filed studies of effects of dichlorvos exposure on acetylcholinesterase activity in the gills of the mussel, Mytilus edulis L. Aquat. Toxicol. 38, 125-143.

Payne, J., Mathieu, A., Melvin, W., Fancey, L.L., 1996. Acetylcholinesterase, an old biomarker with a new future? Field trials in association with two urban rivers and a paper mill in Newfoundland. Mar. Pollut. Bull. 32, 225-231.

Radenac, G., Bocquené, G., Fichet, D., Miramand, P., 1998. Contamination of a dredgedmaterial disposal site (La Rochelle Bay, France). The use of the acetylcholinesterase activity of Mytilus edulis (L.) as biomarker of pesticides : the need for a critical approach. Biomarkers 3, 305-315.

RNO, 1997. Réseau national d'observation de la qualité du Milieu Marin - Surveillance du milieu marin, Ifremer and Ministère de l'Environnement, Paris.

Salte, R., Syvertsen, C., Kjonnoy, M., Fonnum, F., 1987. Fatal acetylcholinesterase inhibition in salmonids subjected to a routine organophosphate treatment. Aquaculture 61, 173-179.

Shigehisa, H., Shiraishi, H., 1998. Biomonitoring with shrimp to detect seasonal change in

river water toxicity. Environ. Toxicol. Chem. 17, 687-694. 
Solé, M., Porte, C. , Barcelo, D., Albaiges, G., 2000. Bivalves residue analysis for assessment of coastal pollution in the Ebro Delta (NW Mediterranean Sea). Mar. Poll. Bull. 40, 746-753. Thomas, K., Thain, J., Waldock, M.J., 1999. Identification of toxic substances in United Kingdom estuaries. Environ. Toxicol. Chem. 18, 401-411.

Thompson, S., Budzinski, H., garrigues, P., Narbonne, J.F., 1999. Comparison of PCB and DDT distribution between Water-Column and sediment-dwelling bivalves in Arcachon bay, France. Mar. Pollut. Bull. 38, 655-662.

Zinkl, J.G., Lockhart, W.L., Kenny, S.A., Ward, F.J., 1991. The effects of cholinesterase inhibiting insecticides on fish. Elsevier, Amsterdam 